\title{
РАЗВИТИЕ АВИАЦИИ КАК ОДИН ИЗ ФАКТОРОВ СТАНОВЛЕНИЯ ПАРАШЮТИЗМА В СССР В 1930-е ГОДЫ
}

Представленная статья посвящена исследованию процесса зарождения авиации в ведущих странах мира, включая нашу страну, в начале XX в., её качественному совершенствованию и количественному росту в период Первой мировой войны и в межвоенный период. В статье аргументированно доказана объективная необходимость внедрения в авиацию парашютов как надежного средства спасения пилотов. При этом обоснована необходимость изобретения принципиально нового средства спасения по сравнению с применяемыми в воздухоплавании, а именно - ранцевого парашюта. Особое внимание уделено в статье процессу превращения парашютов из средства спасения пилотов в боевое средство - средство выброски десантов. В статье приведены данные архивных материалов и периодической печати различных регионов Юга России, позволяющих проанализировать широкий спектр вопросов, связанных с развитием парашютизма в нашей стране в 1930-е гт. - от появления первых подразделений десантников, от организации
Высшей парашютной школы до создания фактически нового рода войск - Воздушно-десантных войск, их широкого применения во время военных учений войск ряда военных округов, что было бы невозможно без развития массового парашютизма, чему способствовало создание обширной сети аэроклубов, парашютных станций и парашютных вышек. Огромную роль при этом сыграли Осоавиахим и комсомол, превратившие развитие авиационного спорта, вюлючая парашютизм, в приоритетное направление своей деятельности. Проанализирован и вклад в развитие парашютизма таких южных регионов, как Кубань, Ставрополье, Адыгея, Кабардино-Балкария. При этом в статье подчеркнуто, что именно Россия является родиной возникновения авиации, изобретения ранцевого парашюта и создания Воздушно-десантных войск.

Ключевые слова: авиация, воздушный флот, Осоавиахим, комсомол, история авиации, вооруженные силы CCCP.

S. V. Kononenko

\section{AVIATION DEVELOPMENT AS ONE OF THE FACTORS IN THE FORMATION OF PARAUTUTISM IN THE USSR IN THE 1930s}

The study analyzes the origin of aviation in the leading countries of the world, including Russia, at the beginning of the 20th century, its qualitative improvement and quantitative growth during the First World War and in the interwar period. The article convincingly proves the objective necessity of introducing parachutes into aviation as a reliable means of saving pilots. At the same time, the necessity of the invention of a fundamentally new means of salvation is justified in comparison with those used in aeronautics, namely, a backpack parachute. The article features the analysis of their use at the final stage of the First World War, from which it follows that the Russian parachutes were much more reliable than the French ones, the latter were in large numbers in service with the Russian army. Special attention is paid to the process of converting parachutes from a means of rescuing pilots into a combat means, a means of dropping airborne troops. The article presents data of archival materials and periodicals of various regions in the south of Russia, which allow to analyze a wide range of issues

На становление советского парашютизма существенное влияние оказал ряд социально-политических, экономических и военно-технических фокторов. Без такого военно-технического срактора, как возникновение и развитие авиации, related to the development of parachuting in the country in the 1930s: from the emergence of the first paratroopers and organization of the All-Union Parachute Center to the establishment of an actual military branch - Airborne troops. The latter were widely used during military exercises of the troops in a number of military districts, which would have been impossible without the development of mass parachutism facilitated by an extensive network of aeroclubs parachute and parachute stations towers. Osoaviakhim and Komsomol played a huge role as they turned the development of aviation sports, including parachuting, into a priority area of their activities. The study analyzes the contribution of such southern regions as the Kuban, Stavropol, Adygea, Kabardino-Balkaria to the development of parachutism. The article emphasizes that it is Russia that is the birthplace of aviation, the invention of a backpack parachute and the creation of the Airborne Forces.

Key words: air fleet, Osoaviakhim, Komsomol, history of aviation, USSR armed forces.

парашютизм так и остался бы на уровне периода воздухоплавания, то есть о появлении Воздушно-десантных войск невозможно было бы вести речь. В свою очередь без развития парашютизма можно было бы забыть о развитии авиации, 
появлении и совершенствовании космонавтики. В этой связи освещение истории и одной, и другой отрасли без учета фактора взаимозависимости не будет продуктивным.

Целью данной статьи является изучение развития парашютизма в контексте эволюции советской авиации в 1930-е гг. Кроме того, необходимо связать поднимаемую проблему с общим историческим контекстом и изменениями в стране. Именно в условиях форсированной индустриализации в СССР была основана авиационная промышленность.

Проблема актуализируется недостаточной разработанностью в науке. В историографии тема представлено только контекстно, комплексного исследования пока не подготовлено. Встречаются отдельные работы о развитии авиации, об истории Воздушно-десантных войск, в предложенной формулировке проблема не освещалась $[5 ; 6 ; 12 ; 13 ; 25]$. Важно отметить, что научная разработка истории парашютизма существенно расширяет исторические знания о состоянии вооруженным сил СССР накануне Великой Отечественной войны.

В целом, одной из общих предпосылок парашютизма в России и мире стало несовершенство первых самолетов и как следствие -жертвы среди пилотов. Например, данное обстоятельство вызвало к жизни ранцевый парашют, изобретателем которого является наш соотечественник Г Е. Котельников. 9 ноября 1911 г. он подал заявку на патент. Вскоре ему было выдано свидетельство на изобретенный им «спасательный ранец для авиаторов с автоматически выбрасываемым парашютом». Сообщение об этом было напечатано в «Вестнике финансов, промышленности и торговли» за 1911 г., №52. Свою первую модель ранцевого парашюта Котельников назвал РК-1, что означало «Русский, Котельникова, первая модель» [8, с.11]. В Советском Союзе впервые применил парашют для спасения своей жизни выдающийся летчик М. М. Громов в 1927 г. во время испытания нового самолета. Машина была введена М. М. Громовым в штопор, сделала несколько витков, после чего самолет потерял управляемость и вывести его из штопора не представлялось возможным. Катастрофра была неминуема, и в этой ситуации пилот воспользовался парашютом, спасшим ему жизнь. Вскоре вслед за М. М. Громовым спомощью парашюта спаслись летчики Писаренко и Бухгольц, после чего он стал обязательной принадлежностью каждого советского летчика $[14$, с. 50]. Таким образом, к началу 1930-х гг в СССР был технический опыт для последующего развития парашютизма, и для военных специалистов было очевидно, что данное средство существенно повышает шансы на спасение жизни летчика в критической ситуации.

Следует отметить, что первые прыжки вызвали огромный интерес к парашютному делу, в том числе среди молодежи. IX съезд комсомола (январь 1931 г) принял решение об организации шефрства над Воздушным флотом страны и выдвинул лозунг «Комсомолец, на самолет!». Фак- тически это был призыв к молодежи овладевать и парашютным делом

История Воздушно-десантных войск своими корнями уходит в 1930-е гт., когда 2 августа 1930 г под Воронежем, на учениях Московского военного округа, был выброшен первый воздушный десант всего из 12 человек, хотя ряд исследователей доказывают, что первый десант на самом деле был выброшен не 2 августа, а 12 августа [9, с. 20].

Этому событию предшествовало другое событие, произошедшее за неделю до первого десанта - 26 июля под тем же Воронежем. Тогда под руководством военного летчика Л.Г Минова состоялись первые в стране учебные парашютные прыжки с самолета, положившие начало зарождению в Советском Союзе парашютизма, а 26 июля в память о первых парашютных прыжках и сегодня отмечается как день парашютиста.

Надо отметить, что стремительный подъем авиационной отрасли был основан на достижениях предшествующего периода. После окончания Гражданской войны с 1921 по 1926 гг. Воздушный флот Красной Армии увеличился по количеству самолетов в 4 раза. В дальнейшем производство самолетов только наращивалось. При этом повышались все летные характеристики самолетов. Так, в период с 1927 по 1934 гг. высота полета отечественных самолетов увеличилась на $153 \%$, скорость - на 165\%, дальность полета - на $273 \%$, а грузоподьемность самолетов - на $1.200 \%$. Все это позволило И.В. Сталину сделать на объединенном пленуме ЦК и ЦКК ВКП(б) в январе 1933 г в докладе об итогах первой пятилетки следующий вывод: «У нас не было авиационной промышленности, у нас она есть теперь» $[23$, л. 10, 9, 10].

Идея применить спасательный парашют как боевое средство для выброски воздушных десантов зародилось в начале 1930-х гг. С этого момента парашютизм стал одним из приоритетных направлений развития вооруженных сил страны. Вскоре начали формироваться первые воздушные десантные части, которые необходимо было обеспечивать квалифицированными кадрами. За решение этой задачи взялись Осоавиахим и ВЛКСМ и буквально за считанные годы страна покрылась сетью аэроклубов, парашютных станций и парашютных вышек, давших стране сотни тысяч парашютистов.

Первые годы ушли на создание парашютного актива, на подготовку инструкторов парашютного спорта. И только в 1933 г. был создан первый Осоавиахимовский кружок, за которым возникли десятки новых кружков, и через которые к развитию парашютизма была привлечена широкая общественность страны и, прежде всего, молодежь. К концу 1933 г. было выпущено уже 1.200 парашютистов.

Ряд решений ЦК ВКП(б), а также Центрального Совета Осоавиахима и ЦК ВЛКСМ [10, с. 36-39] привели к бурному развитию парашютизма в нашей стране в середине 1930-х гг. Огромную роль в развитии парашютизма сыграли создаваемые с 1933-1934 гг. аэроклубы. В 1934 гг. с самолета прыгнуло уже 4.500 человек. В Москве создает- 
ся Высшая парашютная школа, которая готовит инструкторов парашютного спорта. В стране разворачивается широкая сеть парашютных станций и кружков. Строятся сотни парашютных вышек. Они возникают не только в городах, но и в крупных колхозах и совхозах. Всего за один только 1935 г с вышек прыгнуло 800.000 человек [20, с. 4]

Успехи в развитии массового парашютизма неизбежно должны были привести и вскоре привели к созданию первых подразделений десантников и к применению массовых воздушных десантов при проведении войсковых учений. Так, если в 1931 г в Ленинградском военном округе был сформирован первый “отдельный отряд №3» численностью 146 десантников, то к концу 1933 г. в ВВС насчитывалось 8 отдельных десантных батальонов и одна бригада общей численностью около 8000 человек. В последующие предвоенные годы организационная структура ВДВ совершенствовалась, а численность этих войск непрерывно увеличивалась. Если первый десант на учениях Московского военного округа в августе 1930 г. был выброшен в количестве 12 человек, то на учениях Киевского военного округа в сентябре 1935 г. был выброшен десант численностью почти 1.200 человек, который, «захватив» аэродром, обеспечил высадку посадочным способом еще 1765 человек с оружием и боевой техникой. В 1936 г. были проведены еще более масштабные учения с выброской воздушного десанта большой численности: в Белорусском военном округе с парашютами было выброшено 1800 человек, в Московском военном округе 2000 человек [9, с. 126, 158, 172, 180]. На учениях присутствовали иностранные военные наблюдатели, на которых применение такого десанта произвело огромное впечатление

Вышеописанная тенденция активного развития авиации и парашютизма имела конкретное региональное выражение. Опыт Ставрополья и Кубани также демонстрирует повышенный интерес властей и общества к парашютизму. В феврале 1934 года возник аэроклуб в Краснодаре в котором в 1935 г. было подготовлено 9 парашютистов, произведено 16 прыжков с самолета, а на 1936 г. была поставлена задача подготовить 250 парашютистов [19, с. 3].

16 июля 1937 года впервые с самолета на армавирском аэродроме прыгнули курсанты парашютной школы армавирского райсовета Осоавиахима. Прыжки с самолета сделали Черкасов и Евдокимов (консервный завод), Иванов и Васильев (ватная фрабрика), Литвинов (артель «Красное солнце»), Руденко Дуся (студентка плодоовощного техникума), Раиса Адамайтис (швейтруд), Коногоров (артель пищепродукт), который и стал первым парашютистом в Армавире. Под руководством инструктора парашютного спорта Гошко к прыжкам с парашютом готовилось еще 30 человек [22, с. 4].

Летом 1934 г. был открыт аэроклуб и в Нальчике, среди первых выпускников которого были и девушки. Одной из первых выпускниц аэроклуба была Аня Маремукова. По окончании аэроклуба она осталась работать в нем инструктором по прыжкам с парашютом и за время своей работы подготовила не один десяток парашютисток. После возведения в Нальчике парашютной вышки увлечение прыжками стало едва ли не повальным и на начало 1937 г. в Кабардино-Балкарии уже было 165 профессиональных парашютистов. Летную стезю избрала для себя и первая летчица-горянка Леля Дышекова [26].

Достаточно активная работа на Кубани по подготовке летчиков и развитию парашютизма проходила в Адыгее. К счастью, в Национальном архиве Республике Адыгея (НАРА) сохранился фонд P-250, содержащий архивные документы Адыгейского областного аэроклуба им. М. М. Громова, которые позволяют досконально изучить механизм работы как партийных и советских исполнительных органов власти, так и непосредственных организаторов авиационной работы, включая развитие парашютного дела, то есть Осоавиахимовских структур и руководителей аэроклуба.

17 августа 1933 г. Президиум Северо-Кавказского крайисполкома и Северо-Кавказского крайкома ВКП(б) (в Северо-Кавказский край тогда входила и Адыгейская автономная область) принял решение о создании аэроклуба им. Героя Советского Союза М. М. Громова в г. Майкопе, который уже на следующий год должен был подготовить 410 различных специалистов в области авиации, в том числе 50 парашютистов [16, л. 53].

Во исполнение принятого решения 12 ноября 1933 г. состоялось заседание районного комитета содействия развитию гражданской авиации и организации аэроклуба при Майкопском райисполкоме. На заседании отмечалось, что на создание и приобретение материальной части аэроклуба потребуются «громадные денежные средства, ориентировочно - 225-250 тысяч руб.», а поэтому было рекомендовано всем хозяйственным, кооперативным и другим организациям и учреждениям вступить в юридические члены аэроклуба. 20 ноября 1933 г. в помещении Дома обороны было созвано совещание руководителей организаций и учреждений, на котором обсуждался вопрос об организации аэроклуба и вступлении в юридические члены.

Аэроклуб в Майкопе успешно готовил без отрыва от производства пилотов, среди которых было 5 человек адыгейцев, получивших право на самостоятельные полеты: Совмен Рамазан, Гучетль Ахмед, Ташу Хачмиз, Аутлев Хамид, Абреч Мадин [10, с. 4]. Все они имели и парашютную подготовку.

При аэроклубе была создана парашютная станция, в состав которой входила парашютная вышка высотой 27 метров, 9 различных парашютов (тренировочные, десантные, для летчиков, для наблюдателей, учебные), стол для укладки и шкаф для хранения парашютов, парашютные качели, макет кабины самолета У-2, класс для занятий, зал для укладки, укладочные принадлежности. Имелся также аэродром для совершения прыжков, дежурная автомашина и врач для медицинского обеспечения прыжков [18, л. 60]. 
В 1938 г. Центральный Совет Осоавиахима из-за большого количества катастроф с гибелью людей признал состояние парашютной работы в аэроклубах страны неудовлетворительным. Парашютное хозяйство многих станций было запущено, подготовка парашютистов с вышек вышла из руководства аэроклубов и была предоставлена паркам и предприятиям. Центральный Совет потребовал в своем постановлении навести порядок в использовании парашютных вышек, возложить руководство их работой на аэроклубы и райсоветы Осоавиахима, на территории которых они расположены. Начальникам аэроклубов было предоставлено право утверждать открытие и закрытие (пришедших в негодность) парашютных вышек, принадлежащих кому бы то ни было $[18$, л. 34].

Выполняя это постановление, начальник Майкопского аэроклуба капитан Тишкевич, командир парашютного отряда Савенков, вместе с руководителями райсовета Осоавиахима и представителя райкома ВЛКСМ обследовали парашютные вышки Адыгеи и признали некоторые непригодными к эксплуатации. В частности, парашютная вышка, принадлежащая лесокомбинату ст. Апшеронская, имела такие дефекты, которые не обеспечивали безопасность парашютных прыжков. Их перечень был указан в акте от 23 августа 1939 г $[17$, л. 29], а вышка была закрыта до устранения всех дефектов.

Майкопский аэроклуб только в 1939 г. подготовил: перворазников-парашютистов - 163 человека, спортсменов-парашютистов - 11, инструкторов парашютного спорта второй категории - 2 . В 1939 г. парашютная станция работала без единого происшествия и завоевала переходящее Красное Знамя по аэроклубу, выполнив задание по подготовке парашютистов на $125 \%$ [18, л. 23].

В целом аэроклуб в Майкопе сыграл важную роль в деле подготовки для страны авиационных кадров. К началу Великой Отечественной войны он подготовил более 600 летчиков и 300 парашютистов. Все они за проявленное мужество и отвагу в боях против немецко-фашистских захватчиков были награждены орденами и медалями, а четыре человека - А. И. Макаренко, А. К. Шевкунов, Д. В. Зюзин и М. К. Нагулян - были удостоены звания Героев Советского Союза [24].

К сожалению, у нас нет документов, подтверждающих, что в работе Осоавиахимовских организаций Ставрополья одним из приоритетных направлений работы было бурное развитие авиационной работы, включая парашютизм. Так, в материалах об ущербе, нанесенном немецко-фашистскими захватчиками обществам Осоавиахима Ставрополья, нет ничего, что говорило бы о нанесении ущерба авиации, в том числе и парашютному делу. В частности, в акте от 29.06.1943 г указано, что фашисты нанесли обществам Oсоавиахима региона ущерб на общую сумму 792200 рублей. И далее перечисляется то имущество, что было разрушено, уничтожено или расхищено: 23 миномета, 2000 клинков казачьих, 1000 противогазов и т.д. $[4$, л. 2,2 об.].
В принципе, это подтверждают и ряд рапортов местного Осоавиахима Ставропольскому (с 1935 г. - Ворошиловскому) райкому ВКП(б), райисполкому и редакции газеты «Власть Советов». Так, в рапорте к 15-й годовщине Красной Армии в числе достижений райсовета Осоавиахима значатся вскрытие ряда ям со 102 ц. кулацкого хлеба, заготовка 50 ц. семян, организация 4 образцовых военизированных конюшен на 150 лошадей и очищение от грызунов и сусликов 150000 кВ.М полей $[1$, с. 1].

К 17-й годовщине Красной Армии в числе «больших достижений» райсовета Осоавиахима значится завершение военно-политической подготовки допризывников, рожденных в 1913 г; ликвидация среди них неграмотности, 25,1\% членов Осоавиахима стали Ворошиловскими стрелками 1-й ступени, 45,3\% - значкистами ГТО 1-й ступени [22, с. 3].

Факт слабого развития авиационной работы признавали и местные власти. Так, в передовой статье ко Дню Авиации в 1935 г. редакция газеты отмечала: «Ворошиловский район День Авиации встречает с неудовлетворительными показателями. Сделано очень мало ...необходимо все внимание заострить на оживлении работы аэроклуба, ... организации парашютной станции... Ворошиловский район должен иметь своих летчиков, парашютистов, свои аэродромы и посадочные площадки!) [2, с. 1]

После «заострения внимания» действительно дело сдвинулось. Как отмечалось в одной заметке, «после бесконечных отодвиганий сроков строительства парашютной вышки, - вышка выстроена. В силу недостаточности средств, пришлось ограничиться на первый раз высотой вышки в 23 м» [27, с. 4]. Правда, вместо запланированного открытия вышки в День Авиации это произошло почти на неделю позже - 24 августа. О том, что этого события в городе давно ждали, говорит тот факт, что к 5 сентября с парашютной вышки был совершен 371 прыжок с парашютом. При парашютной вышке Осоавиахим открыл выставку парашютного дела, которую только за первый день посетило около тысячи человек [15, с. 3]

Но прошел еще почти год, пока газета не сообщила: «В Ворошиловске впервые начала функционировать парашютная вышка, ставящая целью подготовить парашютистов 1-й ступени. Райсовет Осоавиахима начал заключение договоров с предприятиями, учреждениями и учебными заведениями на подготовку парашютистов») [11, с. 4].

В то же время до крупных успехов в области развития авиационных видов спорта, включая парашютный, было далеко. Такой вывод напрашивается, когда знакомишься с отчетом о работе Орджоникидзевского крайкома профсоюза МТС за время работы с 17.09.1937 г. по 13.11.1939 г. в котором было указано: значкистов ГТ за отчетный период подготовлено 589 человек, летчиков - 3 чел., парашютистов - 8 чел. [3, л. 43-44]. Все-таки для краевого профсоюза, причем объединявшего в техническом отношении наиболее подготовленную часть трудящихся, это явно не- 
значительное количество авиационных спортсменов. Тем не менее, и Ставрополье не оказалось в стороне от развития парашютизма

Таким образом, 1930-е гг. стали периодом прорыва в развитии отечественного парашютизма что было следствием успехов в авиационном деле. Имеющийся технический опыт предшествующего периода получил развитие как в центре так и на местах. В частности, на Ставрополье и
Кубани основывались аэроклубы, которые были призваны готовить специалистов в сфере авиации, главным образом, летчиков и парашютистов. Приметой времени стало активное привлечение к обучению девушек, в том числе и представительниц местных кавказских народов. Сравнительный анализ показал, что Ставрополье имело успехи в авиационной подготовке, но от Кубани и ряда других регионов Юга России отставало.

1. Власть Советов. 1933. 23 февраля

\section{Источники и литература}

2. Власть Советов. 1935. 18 августа.

3. Государственный архив новейшей истории Ставропольского края. Ф.Р-1016. Оп.1. Д.138.

4. Государственный архив Ставропольского края. Ф.Р-1931. Оп.1. Д.200

5. Карташев А.В. История подготовки военных авиаспециалистов в России: 1910-1991: дисс. ...докт. ист. наук. Пятигорск: ПГГТУ, 2012. 612 c.

6. Келдыш М. В., Свищев Г. П., Христианович С. А. и др. Авиация в России: справочник. Изд.2-е, перераб. и доп. М.: Машиностроение, 1988. $368 \mathrm{c}$.

7. Кононенко С. В. Парашютизм В СССР: от зарождения к развитию в первой половине 1930-х гг. // Вестник Екатерининского института. 2017. №2. С.36-39.

8. Корзинкин П. Советский парашютный спорт. М.: ДОСААФ, 1958. 37 с.

9. Котельников В. Р. Красный десант: советские воздушно-десантные войска в предвоенный период. 1930-1941. М.: Русские Витязи, 2014; 200 с.

10. Красное Знамя. 1937. 29 августа

11. Лисоткин. Парашютный спорт // Власть Советов. 1936. 24 июня.

12. Малахов Д. Н. Боевое применение советской авиации в покальный войнах и военных конфликтах в 30 -е годы XX века // Ярославский педагогический вестник. 2009. №.3. С. 218-223.

13. Малахов Д. Н. Организационное строительство ВВС РККА накануне Великой Отечественной войны // Ярославский педагогический вестник. 2010. №2. С.71-75.

14. Минов Л. Овладей парашютом. Краткая история парашютизма. М.: ОГИЗ Молодая Гвардия, 1934. 48 с.

15. На парашютной вышке // Власть Советов.1935. 5 сентября.

16. Национальный архив республики Адыгея (далее - НАРА). Ф.Р-250. Оп. 1. Д. 2.

17. НАРА. Ф.Р-250. ОП. 1. Д. 49.

18. HAPA. Ф.Р-250. Оп. 1. Д. 63.

19. Наш аэроклуб // Красное знамя. 1936. 18 августа

20. Немного истории // Правда. 1936. 14 октября.

21. Новый. Прыжки с парашютом // Армавирская коммуна. 1937. 21 июля.

22. Осоавиахим рапортует// Власть Советов. 1935. 23 февраля.

23. Российский государственный военный архив. Ф.29. Оп. 26. Д. 206.

24. Слажнева Е. Есть одна у них мечта - высота // Майкопские новости. 2015. 27 июля.

25. Соболев Д. А., Хазанов Д. Б. Немецкий след в истории отечественной авиации. М.: «Русское авиационное акционерное общество» (РУСАВИА), 2000. 336 с.

26. Черкесов И. Горянки в небе // Горянка (Нальчик). 2012. 19 сентября.

27. Ястржембский. Парашютная вышка готова // Власть Советов. 1935. 15 августа.

1. Vlast' Sovetov. 1933. February 23. (In Russian)

\section{References}

2. Vlast' Sovetov. 1935. August 18. (In Russian)

3. State archive of recent history of Stavropol region. F.R-1016. Inv.1. D.138. (In Russian).

4. State archive of Stavropol region. F.R-1931. Inv.1. D.200. (In Russian).

5. Kartashev A. V. Istoriya podgotovki voennykh aviaspetsialistov $\vee$ Rossii: 1910-1991 (History of Military Aviation Specialists Training in Russia: 1910-1991): thesis. Pyatigorsk: PSHTU publ., 2012. 612 p. (In Russian).

6. Keldysh M. V., Svishchev G. P., Khristianovich S. A. i dr. Aviatsiya v Rossii (Aviation in Russia). Moscow: Mashinostroenie, 1988. 368 p. (In Russian).

7. Kononenko S. V. Parashyutizm $\vee$ SSSR: ot zarozhdeniya k razvitiyu $\vee$ pervoy polovine 1930-kh gg. (Parachuting in the USSR: From Birth to Development in the First Half of the 1930s) // Vestnik Ekaterininskogo instituta. 2017. No. 2. P. 36-39. (In Russian).

8. Korzinkin P. Sovetskiy parashyutnyy sport (Soviet Parachuting). Moscow: DOSAAF publ., 1958. 37 p. (In Russian).

9. Kotel'nikov V. R. Krasnyy desant: sovetskie vozdushno-desantnye voyska v predvoennyy period. 1930-1941 (Red Airborne: Soviet Airborne Troops in the Prewar Period. 1930-1941). Moscow: Russkie Vityazi, 2014; 200 p. (In Russian)

10. Krasnoe Znamya. 1937. August 29. (In Russian).

11. Lisotkin. Parashyutnyy sport (Parachuting) // Vlast' Sovetov. 1936. June 24. (In Russian). 
12. Malahov D. N. Boevoe primenenie sovetskoj aviacii v lokal'nyj vojnah i voennyh konfliktah v 30-e gody $X X$ veka (Combat use of Soviet aviation in local wars and military conflicts in the 30 s of the twentieth century) // YAroslavskij pedagogicheskij vestnik. 2009. No.3. P. 218-223 (In Russian)

13. Malahov D. N. Organizacionnoe stroitel'stvo VVS RKKA nakanune Velikoj Otechestvennoj vojny (Organizational construction of the Red Army Air Force on the eve of World War (I) // YAroslavskij pedagogicheskij vestnik. 2010. No.2. P. 7175. (In Russian).

14. Minov L. Ovladey parashyutom. Kratkaya istoriya parashyutizma (Master the Parachute. A Brief History of Parachuting). Moscow: OGIZ Molodaya Gvardiya, 1934. 48 p. (In Russian).

15. Na parashyutnoy vyshke (On a Parachute Tower) // Vlast' Sovetov.1935. September 5. (In Russian).

16. National archive of Republic of Adygea (NARA). F.R-250. Inv. 1. D. 2. (In Russian)

17. NARA. F.R-250. Inv. 1. D. 49. (In Russian).

18. NARA. F.R-250. Inv. 1. D. 63. (In Russian).

19. Nash aeroklub (Our Flying Club) // Krasnoe znamya. 1936. August 18. (In Russian).

20. Nemnogo istorii (A Bit of History) // Pravda. 1936. October 14. (In Russian)..

21. Novyy. Pryzhki s parashyutom (New. Skydiving) // Armavirskaya kommuna. 1937. July 21. (In Russian).

22. Osoaviakhim raportuet (Osoaviakhim reports) // Vlast' Sovetov. 1935. February 23. (In Russian).

23. Russian state military archive. F.29. Inv. 26. D. 206. (In Russian).

24. Slazhneva E. Est' odna u nikh mechta - vysota (They Have One Dream - Height) // Maykopskie novosti. 2015. July 27. (In Russian).

25. Sobolev D. A., Hazanov D. B. Nemeckij sled v istorii otechestvennoj aviacii (German mark in the history of domestic aviation). Moscow: RUSAVIA publ., 2000. 336 p. (In Russian)

26. Cherkesov I. Goryanki v nebe (Goryanka in the Sky) // Goryanka (Nal'chik). 2012. September 19. (In Russian).

27. Yastrzhembskiy. Parashyutnaya vyshka gotova (Parachute Tower is Ready) // Vlast' Sovetov. 1935. August 15. (In Russian).

Сведения об авторе

Кононенко Сергей Викторович - преподаватель кафедры тактики и общевоенных дисциплин Краснодарского высшего военного авиационного училища летчиков имени Героя Советского Союза А. К. Серова (Краснодар) / migis-107@mail.ru

Information about the author

Kononenko Sergey - teacher, Chair of tactic and general military disciplines, Krasnodar Higher Military Aviation School for Pilots named after Hero of the Soviet Union A. K. Serov (Krasnodar)/migis-107@mail.ru 